\title{
Genetic diversity in Northern Spain (Basque Country and Cantabria): GM and KM variation related to demographic histories
}

\author{
E Esteban ${ }^{1}$, J M D ugoujon ${ }^{2}$ E G uitard², M T Sénégas ${ }^{2}, C$ M anzano ${ }^{3}$, C de la R úa ${ }^{3}$, \\ $\mathrm{N}$ Valveny ${ }^{1}$ and $\mathrm{P}$ M oral $^{1}$ \\ ${ }^{1} U$ nitat d'A ntropologia, D epartament de Biologia A nimal, Facultat de Biologia, Universitat de Barcelona, Spain \\ ${ }^{2}$ Centre d'I Immunopathologie et de G énétique H umaine, CNRS, CHU de Purpan, Toulouse, France \\ ${ }^{3}$ D epartamento de Biología A nimal y G enética, Facultad de Ciencias, U niversidad del País B asco, Bilbao, Spain
}

\begin{abstract}
Genetic diversity in Northern Spain (SW Europe) was assessed through the analysis of the GM and KM immunoglobulin markers in $\mathbf{5 0 5}$ individuals using a set of 17 allotypes, including the G2M(23) allotype which has been infrequently used before now. The individuals were representative of three anthropologically well-defined populations belonging to two geographically and archaeologically distinct areas in the Basque Country (Guipúzcoa and Alava provinces) and to the mountainous region of Montes de Pas in the province of Cantabria. Gene frequency distributions indicated a high genetic divergence between Montes de Pas and the Basque Country, and a relative degree of heterogeneity between the two Basque regions. The genetic differentiation of Montes de Pas, which is consistent with previous classical polymorphism analyses, suggests a considerable genetic variation range within the lberian Peninsula, possibly higher than that often polarised around the Basque versus non-Basque variation. Analyses of genetic structure show that the major differentiation of Montes de Pas could be related to the historically documented mixed origin of this population. The moderate genetic distances between regions in the Spanish Basque Country could be explained by differential systematic pressures acting through a stronger gene flow in the South than in the more isolated Northern areas. The comparisons with neighbouring populations from the French Pyrenees suggest that the present genetic variation revealed by Ig polymorphisms in SW Europe can be related to historical demographic processes including gene flow and/or low population sizes.
\end{abstract}

Keywords: Immunoglobulins; GM; KM; Basques; Cantabria

Correspondence: Pedro Moral, U nitat d'A ntropologia, Departament de Biologia A nimal, Facultat de Biologia, U niversitat de B arcelona, A v. D iagonal 645, 08028-B arcelona, Spain. Tel: 34340214 61; Fax: 34341108 87; E-mail: pmoral@porthos.bio.ub.es

Received 13 January 1997; revised 9 December 1997; accepted 23 D ecember 1997 


\section{Introduction}

$\mathrm{GM}$ and $\mathrm{KM}$ immunoglobulin (Ig) antigens, along with HLA system, are the classical polymorphisms showing the greatest variation in humans. The GM system is defined by a set of antigens (allotypes) on the I g heavy chains of $\operatorname{lgG} 1, \operatorname{lgG} 2$ and IgG 3 subclasses. Since the genes encoding these subclasses are closely linked on chromosome $14{ }^{1,2}$ the different allotypes of each subclass are inherited in fixed combinations or haplotypes. The KM allotypes located on the constant part of Ig kappa light chains are independently inherited by the Kappa gene on chromosome $2 .{ }^{3}$ Whereas the variation in the $\mathrm{KM}$ system is only noticeable between the main ethnic groups, GM haplotypes have been shown to be a powerful tool in human population genetics due to their high frequency variation between populations. Furthermore, since several haploptypes are specific to certain groups ${ }^{4,5}$ they allow the possibility to evaluate gene flow and admixtures.

Despite the outstanding potential of GM polymorphism, in practice its usefulness to human population studies have been impoverished by the irregular distribution of available data and by the heterogeneity of allotypes tested in the different groups, which poses a problem for comparison purposes. In Europe, for instance, GM distribution has been extensively analysed, but not all different areas are uniformly represented: most surveys did not test for the interesting G 2M (23) allotype that enables discrimination of the most frequent haplotype $G M * 3 ; 5 *, 26,27$ between $\mathrm{GM} * 3 ; . . ; 5 *, 26,27$ and $\mathrm{GM} * 3 ; 23 ; 5 *, 26,27$. Likewise, through the determination of the $\operatorname{GM}(6,15,16,24)$, A frican haplotypes can be accurately distinguished from those originating in western $A$ sia.

This paper deals with $G M$ and $K M$ diversity in three Spanish populations. The study used a complete panel of allotypes. Although studies of GM in Spanish populations have been reported, ${ }^{6-9}$ the lack of informative allotype determinations represents a remarkable gap in information. This study analyses three Spanish samples, coming from the Guipúzcoa and A lava provinces of the Basque Country, and from M ontes de Pas in the Cantabria region (Figure 1 ).

The anthropological and geographic features of the populations examined bring additional interest to this study. The first point refers to the geographic position of the Basque samples in the south-western Pyrenees, the geographical and political border which separates the Iberian Peninsula from the rest of mainland Europe. The genetic landscape of the Pyrenees has

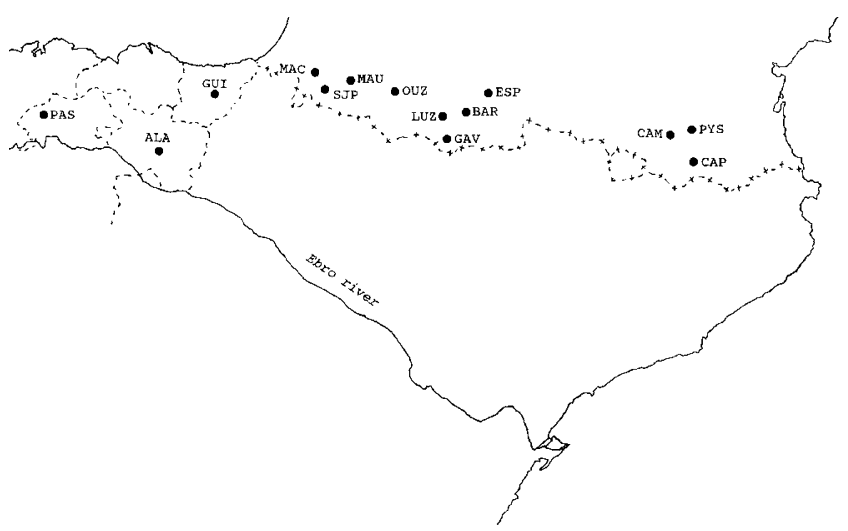

Figure 1 G eographical location of the Spanish and Pyrenean populations. Population abbreviations: PAS: M ontes de Pas; A L A: A lava; GUI: G uipúzcoa; CA P: Capcir; PYS: Pays de Sault; CA M : Camurac; E SP: E sparros; BAR; Barèges; GAV: Gavarnie; L UZ: L uz-St Sauveur; OUZ: Vallée de I'O uzon; MAU: Mauléon; SJP: St Jean de Pied de Port; MAC: Macaye.

been for a long time of interest to anthropologists trying to assess the genetic trail of possible east-west and north-south population interchanges. Some studies, using other classical markers such as blood groups, proteins and HLA antigens, have suggested the existence of an east-west gradient with the genetic distinctiveness of the Basque population at the western extreme. ${ }^{10}$ However, Ig data reported only for the northern side of the Pyrenees ${ }^{11,12}$ seem to suggest greater genetic proximity between the western and central Pyrenees, as against the easternmost part. These first data about the southern side of the Pyrenees will enable the genetic relationships between Pyrenean populations to be analysed better.

Concerning the Basque samples, Guipúzcoa, A lava and Vizcaya are the component provinces of the autonomous region of the $B$ asque Country in northern Spain. There are also B asques in N avarra (Spain) and in the Département des Pyrénées-A tlantiques in southwestern France. The Basques are ethnically distinct from surrounding peoples. Many studies have established their genetic and linguistic peculiarities, considering the present-day $\mathrm{B}$ asques a relic of the ancient population of E urope [see as a review Cavalli-Sforza et $\mathrm{al}^{13}$ ]. This peculiarity has been preserved more fully in Spanish Basques than in French Basques, who have probably had greater influence from abroad. In spite of the numerous surveys on the genetic characteristics of the Spanish Basques, no data on Ig markers have yet been published. A nother question is the homogeneity or heterogeneity of the Spanish Basque population. 
Several studies ${ }^{14,15}$ have suggested a certain degree of genetic heterogeneity, the main subdivision being between North (Guipúzcoa and Vizcaya provinces) and South (A lava province). This differentiation agrees with the geographical subdivision established by the mountain range that constitutes the watershed, and is consistent with other archaeological, ${ }^{16}$ ethnological ${ }^{17}$ and skeletal ${ }^{18}$ differentials. The Ig genetic markers of clearly separated geographical areas of the Spanish $B$ asque Country will enable the hypothesis of $M$ anzano et $\mathrm{al}^{19}$ which distinguishes the 'A tlantic' Spanish Basques in the North (Guipúzcoa and Vizcaya provinces) from the southern group with more 'Mediterranean' influence (A lava province) to be tested.

The study of a particular population, geographically near the Basque Country but non-Basque, from the $M$ ontes de Pas can serve not only to analyse the genetic relationships of $B$ asques with surrounding populations, but also to explore the unique characteristics of this population. Montes de Pas is a rough region encompassing several small and deep-set valleys in the south of the Cantabrian Mountains, between Cantabria and Burgos provinces (North Spain). The human presence in this region could be very ancient due to the existence of natural passes between these two provinces. The oldest historical evidence supports the passage of Romans, and later $V$ isigoths, in order to conquer Cantabria. However, human settlement was probably not constant until the beginning of the 11th century when the award of pastures was historically documented. A t this time, repopulation from neighbouring areas took place, perhaps with small contributions from ethnic minorities. Since the 18th century, the population of the region has fluctuated at around 5000 inhabitants. People from Montes de Pas have a different life style from other people in the Iberian Peninsula. The 'Pasiegos' are shepherds who more seasonally between different cow pastures they own along the mountains. They possess a house in each pasture, so farmhouses are scattered over the mountainous slopes. Their extreme adaptation to the environment has produced a relatively isolated population with little interaction with other parts of the province $(83.7 \%$ of endogamy and $6.1 \times 10^{-3}$ of consanguinity ${ }^{20}$ ); as a result of this, legends about their possibly Moorish or Jewish origins have arisen. In contrast with the Basques, the human population genetics of Montes de Pas are poorly known. At present only data on several protein polymorphisms ${ }^{21}$ are available. The study of Ig genetic variants presented here will provide new information on the genetic structure of this population, its affinities with other neighbouring groups and the patterns of genetic diversity among Iberian Peninsula populations.

\section{Materials and Methods}

A total of 503 individuals coming from three Northern Spanish regions, Guipúzcoa ( $n=112)$, A lava $(n=294)$, and Montes de Pas $(n=100)$, were studied. Blood specimens were collected from adult, unrelated, apparently healthy people of both sexes living in rural areas, and only individuals whose four grandparents were natives of the same region were considered. The Basque samples from Guipúzcoa and A lava were taken from autochthonous individuals of the two provinces. G uipúzcoa, is the smallest of the B asque provinces (1997 square km, and 705933 inhabitants), whose central position has enabled it to preserve its language and ancient traditions more fully than the other two provinces. To the south of the Pyrenees, the province of A lava, with an area of 3074 square $\mathrm{km}$ and 260580 inhabitants, is open to the Ebro basin. The $M$ ontes de Pas sample comes mainly from hamlets scattered in the main valleys of this mountainous region of around 5000 inhabitants.

\section{GM and KM Typing}

Serum samples were typed for $16 \mathrm{GM}$ allotypes belonging to the three IgG subclasses $\operatorname{GIM}(1,2,3,17), \quad \mathrm{G} 2 \mathrm{M}(23)$, G 3M $(5,6,10,11,13,14,15,16,21,24,28)$ and for the $K M(1)$ allotype, according to the standard agglutination inhibition method. ${ }^{22}$ The reagents used are listed in Table 1.

\section{Statistical Analysis}

$\mathrm{H}$ aplotype frequencies were estimated using the maximum likelihood method. ${ }^{23} \mathrm{G}$ oodness of fit to the Hardy-Weinberg equilibrium and allele frequency differences between populations were evaluated by means of the chi-square test. $H$ eterozygosities were estimated as $1-\Sigma x_{i}^{2}$, where $x_{i}$ is the estimated frequency of the $i$-allele in each system.

For comparative purposes, data on other Pyrenean populations were selected from the literature. ${ }^{11}$ Their geographic locations are shown in Figure 1. To quantify the degree of genetic diversity among populations, $\mathrm{F}_{\text {ST }}$ statistic ${ }^{24}$ was used as a measure of the proportion of genetic variance attributable to population subdivision. The significance of $F_{S T}$ was determined by Workman and N iswander' ${ }^{25}$ method. G enetic distances between pairs of populations were calculated by GENDIST program in PHY LIP 3.5c package ${ }^{26}$ according to the methods of Cavalli-Sforza and $\mathrm{E}$ dwards, ${ }^{27}$ R eynolds et al ${ }^{28}$ and $\mathrm{Nei}^{29} \mathrm{R}$ eynolds' distances were selected because these measurements are proportional to the time of population separation if the main differentiation agent is genetic drift, as seems to be the case for human populations at a microgeographical level. Standard errors of the distances were computed by the bootstrap resampling method. ${ }^{30} \mathrm{~A}$ graphical representation was carried out through principal-component analysis of a variance-covariance matrix from original data 
Table 1 Reagents used for GM and KM allotype determination

\begin{tabular}{|c|c|c|c|c|}
\hline System & Chain & Allotype & A nti-allotype & $\begin{array}{l}\text { Coating antigen } \\
\text { (anti-D) }\end{array}$ \\
\hline$\overline{G M}$ & $\begin{array}{l}\gamma^{2} \\
\gamma^{3}\end{array}$ & $\begin{array}{l}\text { G 1M (1) } \\
\text { G 1M (2) } \\
\text { G 1M (3) } \\
\text { G 1M (17) } \\
\text { G 2M (23) } \\
\text { G 3M (5) } \\
\text { G 3M (6) } \\
\text { G 3M (10) } \\
\text { G 3M (11) } \\
\text { G 3M (13) } \\
\text { G 3M (14) } \\
\text { G 3M (15) } \\
\text { G 3M (16) } \\
\text { G 3M (21) } \\
\text { G 3M (24) } \\
\text { G 3M (28) }\end{array}$ & $\begin{array}{l}\text { Don } \\
\text { Sub } \\
\text { Rum } \\
\text { Seg } \\
\text { SH-211 } \\
\text { Pag } \\
\text { Ser } \\
\text { Des } \\
\text { Feu } \\
\text { Bet } \\
\text { Bla } \\
26242 \\
26392 \\
\text { Des } \\
\text { D 2018 } \\
\text { L la } \\
\text { Dor }\end{array}$ & $\begin{array}{l}\text { G an } \\
\text { G an } \\
\text { B ei } \\
\text { G an } \\
\text { D el } \\
\text { E yc } \\
2781^{2} \\
\text { E yc } \\
\text { E yc } \\
\text { E yc } \\
\text { E yc } \\
40952 \\
40952 \\
\text { A nt } \\
2781^{2} \\
\text { A nt }\end{array}$ \\
\hline KM & $\kappa$ & $\mathrm{KM}(1)$ & Por & B ei \\
\hline
\end{tabular}

A nti-allotypes and Anti-D were provided by the Centre R égional de Transfusion Sanguine, d'H ématologie, Immunologie et Génétique Humaine, $\mathrm{CHU}$ de Purpan, Toulouse (France), except for: Iprovided by Sigma-A Idrich Quimica SA ; ${ }^{2}$ provided by the CLB Central Laboratory of the Netherlands Red Cross Blood Transfusion Service, A msterdam (H olland). G ift from D r G de Lange.

(allele frequencies and populations) according to $\mathrm{H}$ arpending $\&$ Jenkins. $^{31}$

\section{Results}

\section{Phenotype and Haplotype Distributions}

GM and KM phenotype distributions are shown in Table 2. Some uncommon phenotypes, all of them previously reported ${ }^{32-34,11} \quad\left[\mathrm{GM}\left(1,2,3,17 ; 23 ; 5^{*}\right)\right.$, $\operatorname{GM}\left(3 ; 23 ; 5^{*}, 21,28\right)$ and $\mathrm{GM}\left(1,3 ; \ldots ; 5^{*}, 21,28\right)$ in A lava; $\operatorname{GM}(1,3,17 ; 23 ; 21,28)$ and $G M(1,3,17 ; 23 ; 10,11,13,15,16)$ in Montes de Pas], were excluded from haplotype calculations, except for the carriers of haplotype $\mathrm{GM} * 1,17 ; 23 ; 21,28$, one of the most frequent among the rare haplotypes. In all cases, phenotype distributions showed no significant deviations from the $\mathrm{Hardy}$ Weimberg equilibrium. Table 3 reports the GM and $\mathrm{KM}$ haplotype frequencies with the estimated confidence intervals.

$\mathrm{H}$ eterogeneity for the distribution of $\mathrm{GM}$ was observed among the three populations examined $\left(\chi_{8}^{2}=17.458, P=0.025\right)$. Pairwise comparisons also revealed significant differences (Table 4) for several G M haplotypes. U nlike for G M , similar frequencies for
$\mathrm{KM}$ alleles were found among the three populations (Table 3).

\section{Spanish Haplotype Frequencies within the European Variation}

In relation to $G M$ and $K M$ variation in Europe (Table $5)$, the most remarkable findings were the high $G M * 3 ; 23 ; 5 *$ frequency of Guipúzcoa and the low $G M * 3 ; 5 * \quad(G M * 3 ; . ; 5 *$ and $G M * 3 ; 23 ; 5 *$ combined) value in $M$ ontes de Pas. A lso the $G M * 1,17 ; ., ; 21,28$ frequency in $M$ ontes de Pas was relatively high in comparison with both $\mathrm{E}$ urope and $\mathrm{N}$ orth A frica.

The $G M * 1,17 ; ., ; 5^{*}$, characteristic of black $A$ frica $^{5}$ and also frequent in North A frica, is present in A lava and Montes de Pas but absent in Guipúzcoa. The $\mathrm{GM} * 1,17 ; ., ; 10,11,13,15,16$, particularly common in A sian populations ${ }^{5}$ but rare or absent in most of $\mathrm{N}$ orth and $C$ entral $E$ urope, was found in the three populations examined, the Guipúzcoa and Montes de Pas values lying among the highest so far described in E urope and N orth A frica (Table 5).

Table 2 GM and KM phenotypes distribution, $\mathrm{H}$ ardyWeinberg equilibrium and heterozygosities in the $\mathrm{G}$ uipúzcoa, A lava and $M$ ontes de Pas populations

\begin{tabular}{|c|c|c|c|}
\hline Phenotypes & G uipúzcoa & A lava & Mt. de Pas \\
\hline \multicolumn{4}{|l|}{ GM } \\
\hline $3 ; 23 ; 5 *$ & 46 & 98 & 27 \\
\hline $3 ;. . ; 5^{*}$ & 2 & 10 & 3 \\
\hline 1,$17 ; . ., 21,28$ & 8 & 24 & 9 \\
\hline $1,2,17 ; . ., 21,28$ & 1 & 10 & 2 \\
\hline 1,$17 ;. . ; 5 *, 21,28$ & 0 & 3 & 1 \\
\hline $1,3,17 ; 23 ; 5^{*}, 21,28$ & 29 & 66 & 22 \\
\hline $1,3,17 ; . . ; 5^{*}, 21,28$ & 12 & 38 & 17 \\
\hline $1,2,3,17 ; 23 ; 5^{*}, 21,28$ & 5 & 20 & 3 \\
\hline $1,2,3,17 ; . ., 5 *, 21,28$ & 4 & 12 & 2 \\
\hline $1,3,17 ; 23 ; 5^{*}$ & 0 & 3 & 3 \\
\hline $1,3,17 ; . ., 5^{*}$ & 0 & 2 & 0 \\
\hline $1,2,17 ; 23 ; 21,28$ & 0 & 1 & 0 \\
\hline 1,$17 ; 23 ; 21,28$ & 2 & 1 & 0 \\
\hline $1,3,17 ; 23 ; 5^{*}, 15,16$ & 0 & 2 & 1 \\
\hline 1,$17 ;. . . ; 10,11,13,15,16,21,28$ & 0 & 1 & 3 \\
\hline 1,$17 ;. ., 5^{*}$ & 0 & 2 & 0 \\
\hline 1,$3 ; 23 ; 5^{*}$ & 0 & 1 & 0 \\
\hline $1,3,17 ; . . ; 5^{*}, 15,16$ & 2 & 0 & 5 \\
\hline $\mathrm{N}$ & 111 & 294 & 98 \\
\hline & $0.1101_{0.999}^{10}$ & $3.3013_{0.986}^{11}$ & $1.5063_{0.997}^{9}$ \\
\hline H eterozygosity & 0.669 & 0.710 & 0.723 \\
\hline \multicolumn{4}{|l|}{ KM } \\
\hline KM (1) & 12 & 36 & 14 \\
\hline KM $(-1)$ & 99 & 258 & 86 \\
\hline $\mathrm{N}$ & 111 & 294 & 100 \\
\hline
\end{tabular}

$5^{*}=5,10,11,13,14$.

df degree of freedom.

Pprobability. 
Table 3 GM haplotype and KM frequencies (confidence intervals in parentheses)

\begin{tabular}{|c|c|c|c|}
\hline GM haplotypes & Guipúzcoa & A lava & M ontes de Pas \\
\hline 1,$17 ;. . ; 21,28$ & $\begin{array}{l}0.2567 \\
(0.196-0.326)\end{array}$ & $\begin{array}{l}0.2840 \\
(0.243-0.323)\end{array}$ & $\begin{array}{c}0.3227 \\
(0.252-0.392)\end{array}$ \\
\hline $1,2,17 ; . . ; 21,28$ & $\begin{array}{l}0.0446 \\
(0.022-0.078)\end{array}$ & $\begin{array}{l}0.0749 \\
(0.054-0.104)\end{array}$ & $\begin{array}{l}0.0359 \\
(0.015-0.070)\end{array}$ \\
\hline $3 ;. . ; 5^{*}$ & $\begin{array}{l}0.1867 \\
(0.126-0.256)\end{array}$ & $\begin{array}{l}0.2072 \\
(0.167-0.257)\end{array}$ & $\begin{array}{l}0.2298 \\
(0.159-0.309)\end{array}$ \\
\hline $3 ; 23 ; 5^{*}$ & $\begin{array}{l}0.4770 \\
(0.396-0.556)\end{array}$ & $\begin{array}{l}0.3996 \\
(0.349-0.449)\end{array}$ & $\begin{array}{l}0.3409 \\
(0.270-0.420)\end{array}$ \\
\hline 1,$17 ;. . . ; 5^{*}$ & - & $\begin{array}{l}0.0254 \\
(0.014-0.041)\end{array}$ & $\begin{array}{l}0.0253 \\
(0.008-0.055)\end{array}$ \\
\hline 1,$17 ;. . ; 10,11,13,15,16$ & $\begin{array}{l}0.0177 \\
(0.005-0.042)\end{array}$ & $\begin{array}{l}0.0017 \\
(0.0002-0.0078)\end{array}$ & $\begin{array}{l}0.0455 \\
(0.021-0.082)\end{array}$ \\
\hline 1,$17 ; 23 ; 21,28$ & $\begin{array}{l}0.0173 \\
(0.002-0.052)\end{array}$ & $\begin{array}{l}0.0056 \\
(0.001-0.018)\end{array}$ & - \\
\hline 1,$3 ; \pm 23 ; 5^{*}$ & - & $\begin{array}{l}0.0017 \\
(0.0002-0.0078)\end{array}$ & - \\
\hline $\begin{array}{l}\mathrm{KM} \\
\mathrm{KM} * 1+\mathrm{KM} * 1,2 \\
\mathrm{KM} * 3\end{array}$ & $\begin{array}{l}0.0556 \\
0.9444\end{array}$ & $\begin{array}{l}0.0632 \\
0.9368\end{array}$ & $\begin{array}{l}0.0726 \\
0.9274\end{array}$ \\
\hline
\end{tabular}

$5^{*}=5,10,11,13,14$.

Table 4 Significant differences for several G M haplotypes in the three populations studied

\begin{tabular}{lll}
\hline Haplotype & Population comparisons & \\
\hline Common G M haplotypes & M ontes de Pas-G uipúzcoa & $\chi_{4}^{2}=9.884, P=0.042$ \\
& M ontes de Pas-A lava & $\chi_{4}^{2}=10.497, P=0.032$ \\
G $* 1,17 ; . . ; *$ & Guipúzcoa-A lava & $P=0.007$ \\
$G M * 1,17 ; . . ; 10,11,13,15,16$ & G uipúzcoa-M ontes de Pas & $P=0.022$ \\
& A lava-G uipúzcoa & $P=0.032$ \\
& A lava-M ontes de Pas & $P<0.001$ \\
\hline
\end{tabular}

$\chi^{2}$ degree of freedom.

In italics, Fisher exact probability.

Table 5 Variation ranges for GM and KM systems in E uropean and North A frican populations

\begin{tabular}{|c|c|c|c|c|c|c|}
\hline & \multicolumn{3}{|c|}{ E urope } & \multicolumn{3}{|c|}{ North A frica } \\
\hline & $n^{1}$ & R ange & E xtreme samples & $\mathrm{n}$ & Range & E xtreme samples \\
\hline $\begin{array}{l}\text { G M haplotypes } \\
1,17 ; . . ; 21,28 \\
1,2,17 ; . . ; 21,28 \\
3 ; 5^{*} \\
3 ; . . ; 5^{*} \\
3 ; 23.5^{*} \\
1,17 ; . . ; 5^{*} \\
1,17 ; . ; 10,11,13,15,16 \\
1,17 ; 23 ; 21,28\end{array}$ & $\begin{array}{l}34 \\
34 \\
34 \\
112 \\
11 \\
34 \\
34 \\
11\end{array}$ & $\begin{array}{l}0.088-0.349 \\
0.007-0.147 \\
0.554-0.854 \\
0.167-0.308 \\
0.295-0.474 \\
0.000-0.041 \\
0.000-0.005 \\
0.000-0.022\end{array}$ & $\begin{array}{l}\text { Croatia/FrenchPyr. } \\
\text { Sardinia/N orway } \\
\text { FrenchPyr./Sardinia } \\
\text { Camurac/P. Sault } \\
\text { V. O uzon/B arèges } \\
\text { Several/French Pyr. } \\
\text { Several/French Pyr. } \\
\text { Several/L uzSt. Sav. }\end{array}$ & $\begin{array}{l}7 \\
7 \\
7 \\
6 \\
6 \\
7 \\
7 \\
6\end{array}$ & $\begin{array}{l}0.206-0.308 \\
0.000-0.051 \\
0.400-0.718 \\
0.085-0.303 \\
0.274-0.535 \\
0.063-0.266 \\
0.000-0.007 \\
0.000-0.007\end{array}$ & $\begin{array}{l}\text { K esra B.3/D ouiret B. } \\
\text { Several B./Tunisia G.4 } \\
\text { Takrouna B./K esra B. } \\
\text { Tunisia G./D ouiret B. } \\
\text { Takrouna B./K esra B. } \\
\text { K esra B./Takrouna B. } \\
\text { Several B./Tunisia G. } \\
\text { Several B./Tunisia G. }\end{array}$ \\
\hline $\begin{array}{l}\text { K M system } \\
K M * 1+K M * 1,2\end{array}$ & 34 & $0.033-0.100$ & A ustria/Sardinia & 7 & $0.121-0.205$ & K esra B./D ouiret B. \\
\hline
\end{tabular}

$\mathrm{I}_{\mathrm{n}}$ is the number of studies reviewed. The sources of data are the general collections of Steinberg \& Cook [5], completed, for particular cases, with data from B lanc \& D ucos [32], D ougoujon et al. [11], Pizza et al. [33], L efranc et al. [34], Chaabani et al. [35], Chaabani \& Cox [36], H elal et al. [37] and D ugoujon et al. [38].

20 nly data from French Pyrenean populations were available.

3B, Berber population from Tunisia.

${ }^{4} \mathrm{G}, \mathrm{G}$ eneral non-B erber population from Tunisia. 
A s for $K M$ allotypes, the observed frequencies $K M * 1+K M * 1,2$ in the Spanish samples range within the variation described in Europe and are noticeably lower than in North A frica (Table 5).

\section{Comparisons between Populations from Pyrenees}

The genetic relationships between the three Spanish populations were assessed in comparison with other historic and geographically related groups from the French Pyrenees ${ }^{11,12}$. A first approach to interpopulation heterogeneity was tested by contingency chisquare test and Wright's $F$ statistics. The chi-square analysis indicates remarkable divergences between the three Spanish samples and the eleven French Pyrenean groups, Montes de Pas being the most differentiated (all comparisons were significant), followed by Guipúzcoa ( 5 out of 11 values were significant) and $A$ lava ( 4 out of 11 differences were significant). For $K M$, none of the 33 comparisons was statistically significant. The total number of significant differences (20 out of 66 comparisons) is clearly higher than that expected by pure chance (3.3, at a significant level of 0.05 ).

$\mathrm{F}_{\mathrm{ST}}$ values for interpopulation differentiation are given in Table 6 . The $F_{S T}$ for $G M$ reveals a significant (at the 0.001 level) degree of variation across the 14 populations considered, and also across the more strictly Pyrenean groups, if the geographically separate population of $M$ ontes de $P$ as is excluded. These values are similar in magnitude to values found among Mediterranean regions for 15 genetic markers. ${ }^{39}$ The $F_{\text {ST }}$ values obtained from $\mathrm{KM}$ were substantially smaller than those for GM. On trying to find a geographic pattern of gene variation, a hierarchical $F_{\text {ST }}$ analysis of the Pyrenean populations grouped into three main regions (Western, Central and Eastern Pyrenees, Table 6) indicated that there was no differentiation among regions, the diversity within regions being equivalent to the total interpopulation divergence (Table 6). $F_{\text {ST }}$ values for separate regions showed significant genetic heterogeneity for Central and Eastern regions, in contrast to the homogeneity present in the Western group composed of $5 \mathrm{~B}$ asque populations (three from France and two from Spain).

Pairwise genetic distances, based on GM and KM gene frequencies, between the three Spanish samples and 11 French Pyrenean populations are shown in Table 7 , along with their bootstrap errors indicating that most of the distance estimates (83.5\%) are significantly different from zero. A mong Spanish groups, the largest differentiation corresponded to the Montes de PasGuipúzcoa comparison (genetic distance $=16.3 \times 10^{-3}$ ), whereas A lava Basques were equidistant from those populations with a three-fold smaller distance. An analysis of the intra-Spanish distances inside the overall Pyrenean variation [distance range: $1.1-34.1\left(\times 10^{-3}\right)$ ] shows that: i) $67 \%$ of the values in Table 7 are low (lesser than $10 \times 10^{-3}$ ), pointing to overall genetic homogeneity; ii) within the remaining largest distances, most of them $(87 \%)$ correspond to the comparisons involving Vallée de l'Ouzon, Pays de Sault and Montes de Pas, which appear as clear outliers in a neighbour-joining tree (data not shown).

Figure 2 displays a principal-component analysis map from both populations and alleles. The first three scaled eigenvectors account for $32.9 \%, 23.3 \%$, and $18.3 \%$, respectively ( $74.4 \%$ accumulated) of the total variance. In the population plot on the first two axes (Figure 2a), the first component differentiates $M$ ontes de Pays from Pyrenean populations, in line with its geographic location and its particular origin. The second axis reflects a differentiation within the Pyrenees with a peripheral position of several groups such as Vallée de I'Ouzon and Pays de Sault on the one hand, and Guipúzcoa Basques and Luz-St Sauveur on the other.

Table 6 Gene diversity analysis in Pyrenean populations

\begin{tabular}{|c|c|c|c|c|c|c|c|}
\hline \multirow[b]{3}{*}{ L ocus } & \multirow{2}{*}{\multicolumn{3}{|c|}{$\mathrm{H}$ ierarchical F-statistics }} & \multicolumn{4}{|c|}{ Non-hierarchical F-statistics } \\
\hline & & & & \multirow{2}{*}{$\begin{array}{l}\text { West }{ }^{+} \\
(n=5)\end{array}$} & \multirow{2}{*}{$\begin{array}{l}\text { Central+ } \\
(n=5)\end{array}$} & \multirow{2}{*}{$\begin{array}{l}\text { E ast }^{+} \\
(n=3)\end{array}$} & \multirow{2}{*}{$\begin{array}{l}\text { All populat. } \\
(n=14)\end{array}$} \\
\hline & ${ }^{1} F_{P R}$ & $2 \mathrm{~F}_{\mathrm{RT}}$ & $3 \mathrm{~F}_{\mathrm{PT}}$ & & & & \\
\hline$\overline{\mathrm{GM}}$ & 0.007 & 0.000 & $0.007^{*}$ & 0.000 & $0.008^{*}$ & $0.007 *$ & $0.007^{*}$ \\
\hline $\mathrm{KM}$ & 0.002 & 0.000 & 0.001 & 0.003 & 0.000 & 0.000 & 0.001 \\
\hline A verage & 0.006 & 0.000 & $0.006 *$ & 0.001 & $0.007 *$ & $0.006 *$ & 0.006 \\
\hline
\end{tabular}

$\mathrm{IF}_{\mathrm{PR}}$ : gene diversity among populations $(P)$ within regions $(R)$.

$2 \mathrm{~F}_{\mathrm{RT}}$ : gene diversity among regions.

$3 \mathrm{~F}_{\mathrm{PT}}$ : total gene diversity among populations.

* Significance with $\mathrm{P}<0.001$.

+Populations: West (M acaye, M auleon, St Jean de Pied de Port, A lava, G uipúzcoa); Central (E sparros, Vallée de I'O uzon, L uz-St Sauveur); E ast (Capcir, Pays de Sault, Camurac). In A Il populations, M ontes de Pas has also been included. 
Table 7 Reynolds genetic distance $(\times 1000)$ below diagonal. Standard errors $(\times 1000)$ above diagonal. Population abbreviations defined as in Figure 1

\begin{tabular}{|c|c|c|c|c|c|c|c|c|c|c|c|c|c|c|}
\hline & CAP & PYS & CAM & ESP & OUZ & LUZ & GAV & BAR & $\mathrm{MAC}$ & $\mathrm{MAU}$ & SJ P & GUI & $A L A$ & PAS \\
\hline$\overline{C A P}$ & & 3.6 & 1.1 & 1.2 & 5.4 & 4.7 & 1.0 & 2.7 & 2.0 & 1.3 & 2.3 & 3.6 & 1.3 & 4.1 \\
\hline PYS & 9.7 & & 10.0 & 4.7 & 2.6 & 9.1 & 8.6 & 10.1 & 6.1 & 3.8 & 5.8 & 9.0 & 4.9 & 3.0 \\
\hline CA M & 3.6 & 20.2 & & 1.0 & 10.2 & 2.8 & 0.7 & 1.5 & 3.9 & 2.3 & 1.2 & 2.1 & 1.3 & 4.7 \\
\hline E SP & 1.6 & 10.1 & 2.5 & & 5.8 & 3.5 & 1.5 & 1.0 & 1.7 & 0.8 & 1.1 & 2.2 & 0.4 & 2.3 \\
\hline OUZ & 15.3 & 8.5 & 24.6 & 16.1 & & 4.8 & 4.5 & 12.2 & 12.8 & 8.4 & 10.0 & 11.8 & 3.8 & 2.2 \\
\hline LUZ & 9.8 & 17.7 & 7.9 & 7.4 & 10.5 & & 2.6 & 2.9 & 8.2 & 5.4 & 3.2 & 3.5 & 1.6 & 2.6 \\
\hline GAV & 2.7 & 15.1 & 2.2 & 2.9 & 17.5 & 5.9 & & 3.6 & 2.8 & 2.0 & 3.0 & 4.0 & 1.4 & 4.4 \\
\hline BA R & 7.7 & 21.9 & 1.6 & 3.6 & 27.6 & 8.2 & 5.2 & & 3.9 & 1.7 & 1.4 & 1.1 & 2.3 & 7.2 \\
\hline MAC & 8.2 & 14.2 & 9.5 & 7.0 & 34.1 & 23.8 & 11.4 & 9.4 & & 0.4 & 4.0 & 2.5 & 2.5 & 6.6 \\
\hline MAU & 2.9 & 9.1 & 4.5 & 1.9 & 21.7 & 13.3 & 5.0 & 5.3 & 1.8 & & 2.0 & 1.2 & 1.1 & 3.7 \\
\hline SJP & 4.0 & 16.5 & 2.3 & 2.5 & 22.6 & 9.3 & 6.4 & 2.9 & 8.2 & 4.0 & & 2.0 & 1.4 & 4.8 \\
\hline GUI & 8.0 & 20.7 & 2.9 & 4.7 & 30.2 & 11.1 & 6.6 & 1.3 & 6.3 & 4.0 & 2.9 & & 2.3 & 6.9 \\
\hline$A L A$ & 2.7 & 8.4 & 3.7 & 1.1 & 11.3 & 3.9 & 2.0 & 4.6 & 9.8 & 3.3 & 4.5 & 5.7 & & 1.8 \\
\hline PA S & 11.1 & 8.1 & 15.5 & 8.7 & 4.9 & 5.9 & 11.7 & 15.2 & 23.0 & 13.0 & 13.4 & 16.3 & 5.4 & \\
\hline
\end{tabular}

This second component also reveals the genetic divergence between the two Spanish Basque groups, A lava lying closer to the average population variation. The particular contribution of each allele to the variation along the first two axes (Figure 2b) identifies $\mathrm{GM} * 1,17 ; ., ; 10,11,13,15,16$ and $\mathrm{G} \mathrm{M} * 1,17 ; ., ; 21,28$ alleles as highly associated with Montes de Pas divergence,
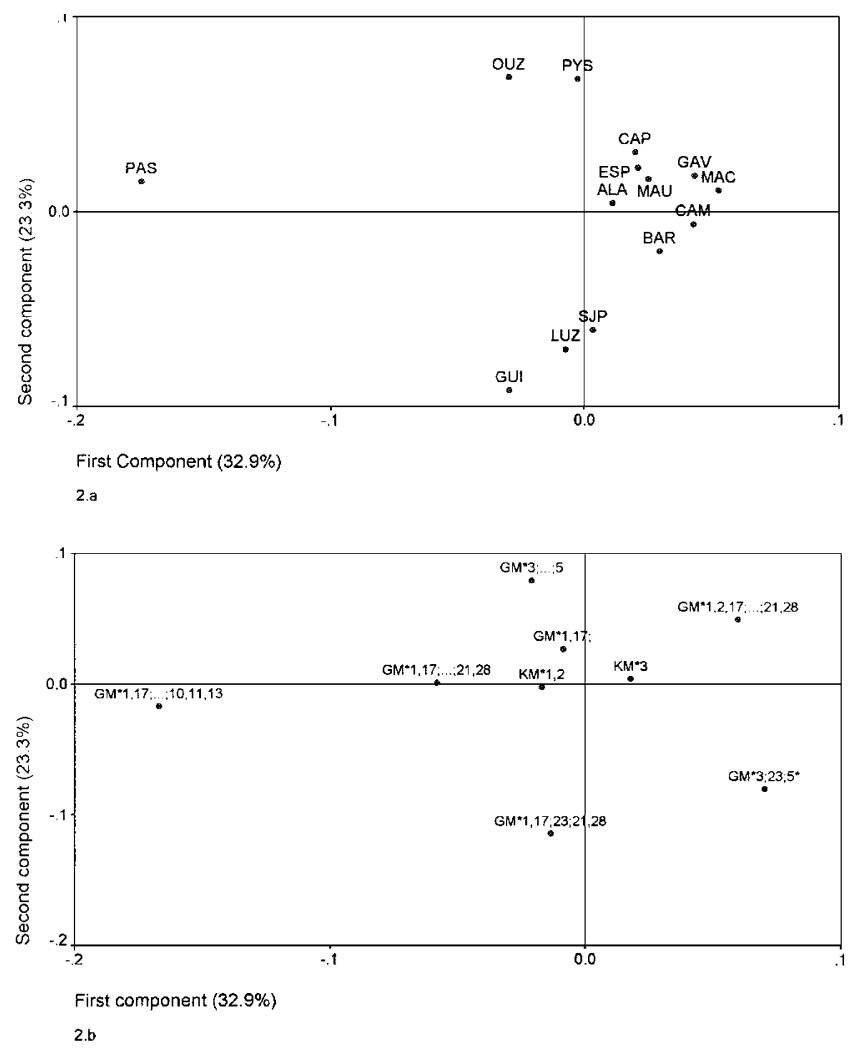

Figure 2 Populations (2a) and haplotypes (2b) plotted on first two scaled eigenvectors. and $\mathrm{GM} * 1,17 ; 23 ; 21,28, \mathrm{GM} * 3 ; 23 ; 5 *$ and $\mathrm{GM} * 3 ; ., ; 5 *$ as mainly correlated with within-Pyrenees differentiation.

\section{Discussion}

The analysis of the Ig haplotypes discussed below is based on the most complete allotype information tested to date on Spanish populations, particularly with the determination of the G 2M (23) al lotype that enables the frequent European haplotype $G M * 3 ; 5 *$ to be subdivided. This subdivision may be useful for detecting underlying genetic variation at a local level, as demonstrated by the absence of significance in the M ontes de Pas-Guipúzcoa comparison when their haplotypes were joined $\left(\chi_{3}^{2}=5.75, P=0.124\right)$ and the important role of these haplotypes for detecting genetic differentiation among Pyrenean populations, as seen in Figure 2.

Concerning the Ig gene distribution in Northern Spain, the major findings of this study are the high genetic divergence between Montes de Pas and $B$ asques and a relative degree of differentiation between the two Basque groups. A t first glance, the major differentiation of $M$ ontes de Pas could be thought to be due to the genetic peculiarity of Basque people, but comparisons with other Spanish groups (unpublished data), the Pyrenees and other continental populations emphasise that the outlying features of Montes de Pas, rather than Basque peculiarity, are responsible for such divergence. In fact, M ontes de Pas has more extreme $G M$ frequencies than Basques for $\mathrm{GM} * 1,17 ; 21,28$ (near to maximum), GM*3;5* (near to minimum) and $G M * 1,17 ; ., ; 10,11,13,15,16$ (maximum) 
within European haplotype ranges (see Table 5). This local variation is discussed in relation to the above issues in the Introduction.

This new information on Ig markers fails to demonstrate that the significant genetic variation in the Pyrenean area could be associated with any particular geographic pattern. The higher intra- than inter-region GM genetic diversity observed is not consistent with the subdivision into three geographic regions. Besides, the facts that the gene differentiation within the Central and the Eastern Pyrenees is as high as in the whole area, and that the lower between-region average distance corresponds to the comparison between the two extremes (West-E ast), do not support any W-E gradient for GM haplotype Pyrenean variation. Through a different analysis our results agree with those of D ugoujon et al ${ }^{11}$ and $\mathrm{H}$ azout et al, ${ }^{12}$ identifying an overall genetic homogeneity among Pyrenean populations with several outliers irregularly distributed. These particular groups, represented mainly by Vallée de l'O uzon and to a lesser degree by Pays de Sault and Luz-St Sauveur, account for most overall diversity because when they were discarded no heterogeneity was apparent $\left(F_{S T}=0.001\right.$, for both $G M$ and $K M$ systems). It seems as if the Ig variation pattern in the Pyrenees should be related to local microdifferentiation processes reflecting unique historical events rather than ancient general settlement patterns. Since there is no reason to suspect heterogeneity in selection pressures in this restricted area, genetic drift and gene flow are the presumed agents responsible for the observed GM haplotype differentiation.

In spite of the general homogeneity of the Basque groups in the context of Pyrenean populations, they show a certain degree of differentiation that can be related to geography and population dynamics. The GM haplotype distribution in Guipúzcoa denotes a relatively specific position for this population (see Figure 2) which appears characterised by the highest $\mathrm{GM} * 3 ; 23 ; 5 *, \quad \mathrm{GM} * 1,17 ; . ; 10,11,13,15,16$ and $\mathrm{GM} * 1,17 ; 23 ; 21,28$ frequencies and the lowest value for $\mathrm{GM} * 3 ; . . ; 5^{*}$ among $B$ asque groups. This relative divergence of $\mathrm{G}$ uipúzcoa could be related to a higher degree of isolation than the A lava population and is consistent with the information from other markers showing a certain genetic differentiation among Spanish Basque regions according to geographical, cultural and anthropometric variation. ${ }^{15,19}$ The most striking differences from A lava are a significant absence of $\mathrm{GM} * 1,17$; . .; $5 *$ and $a$ higher presence of $\mathrm{GM} * 1,17 ; ., ; 10,11,13,15,16$ haplotype. If the presence of $A$ frican $G M * 1,17$; . ;5* haplotype in the Iberian Peninsula is presumably related to the Moslem invasion in 8th century, then its absence in Guipúzcoa is consistent with historical records indicating that Muslims did not conquer this region, as well as a general isolation from southern population influences. More difficult to explain is the frequency of $\mathrm{GM} * 1,17 ; ., ; 10,11,13,15,16$ which has an assumed west $A$ sian origin and could have followed various paths into European populations. Its presence in G uipúzcoa may reflect a northern influence, perhaps very ancient. As for the recombinant haplotype G $M * 1,17 ; 23 ; 21,28$ described as associated to a genetic anomaly, it can be found scattered in French populations and no relevant information can be gained from its presence in the two Spanish B asque samples. B ut the greater number GM haplotypes found in A lava support more external influences, in line with its geographical location near the Ebro river valley, a communication path for Mediterranean peoples since prehistoric times.

The most unusual distribution in the Ig analysis corresponds to the Montes de Pas population, which shows extreme frequencies for some common and uncommon GM haplotypes within the European variation. In particular, concerning other south-west E uropean groups, the I $g$ haplotype distribution of $M$ ontes de Pas is characterised by a relatively high incidence of $\mathrm{GM} * 1,17 ; ., ; 5 *$ and $\mathrm{GM} * 1,17 ; ., ; 10,11,13,15,16$ haplotypes. A ccording to historical information, the origin of the present population could be traced back to the 11th century with the resettlement of people from different regions, including M oslem slaves, giving rise later to an endogamous isolated population. Although more robust conclusions remain to be drawn from consideration of many more loci, our analysis of the $\mathrm{GM}$ and $\mathrm{KM}$ genetic regions shows that instances such as the $M$ ontes de Pas population increase the range of genetic variation in the I berian Peninsula and illustrates how current local genetic variation can be related, at least in some cases, to quite recent historic and demographic processes.

\section{Acknowledgements}

This work was supported in part by D.G.I.C.Y.T. PB 95-0277-C 02-02 and A gencia Española de Cooperación Internacional grants, the Centre $\mathrm{N}$ ational de la Recherche 
Scientifique, and by a Commissionat per a U niversitats $\mathrm{i}$ R ecerca de la G eneralitat de Catalunya grants to E.E. and N.V. Thanks to John Clayton and A ndré Sevin (CIGH, CNRS) for their help in the estimation of haplotype frequencies

\section{References}

1 Croce CM, Shander M, M artinis J et al: Chromosomal location of the genes for human immunoglobulin heavy chains. Proc Natl A cad Sci USA 1979; 76: 3416-3419.

2 Kirsch IR, Morton CC, Nakahara K, Leder P: Human immunoglobulin heavy chain genes map to a region of translocations in malignant B lymphocytes. Science 1982; 216: 301-303.

$3 \mathrm{MCB}$ ride OW, Hieter PA, Hollis G F, Swan D, Otey M C, Leder P: Chromosomal location of human kappa and lambda immunoglobulin light chain constant region genes. J Exp M ed 1982; 155: 1480-1490.

4 Schanfield M S, van Loghem E: H uman immunoglobulin allotypes. In: Weir DM (ed) Genetics and Molecular Immunology. $\mathrm{H}$ andbook of Experimental Immunology, Blackwell Scientific Publications, 1986, vol. 3, pp 1-18.

5 Steinberg AG, Cook CE: The Distribution of $\mathrm{H}$ uman Immunoglobulin Allotypes. Oxford University Press, 1981.

6 Schanfield MS, B aylerian R, M aiquez J, Carbonell F: Immunoglobulin allotypes in European populations. IV. $\mathrm{Gm}, \mathrm{A} \mathrm{m}$ and $\mathrm{Km}$ allotypic markers in Valencia, Spain. J Immunogenet 1981; 8: 529-532.

$7 \mathrm{H}$ ernández $\mathrm{M}$ : Some genetic markers in Catalonia. G ene G eography 1987; 1: 189-191.

8 A Imuzara I, M artínez-Jarreta B, Castellano M: Distribution of $\mathrm{G} 1 \mathrm{~m}(1), \mathrm{G} 1 \mathrm{~m}(2)$ and $\mathrm{G} 3 \mathrm{~m}(5)$ allotypes in A ragón. $\mathrm{H}$ um Hered 1991; 41: 409-410.

9 M oreno $\mathrm{P}, \mathrm{M}$ atsumoto $\mathrm{H}$ : I mmunoglobulin ( $\mathrm{G} \mathrm{m}$ and $\mathrm{K} \mathrm{m}$ ) allotypes in two populations of Catalonia (Spain). A m J Phys A nthrop 1991; 85: 385-338.

10 Calafell F, Bertranpetit J: M ountains and genes: Population history of the Pyrenees. Hum Biol 1994; 66: 823-842.

11 D ugoujon J M, Clayton J, Sevin A, Constans J, L oirat F, $\mathrm{H}$ azout S: Immunoglobulin ( $\mathrm{Gm}$ and $\mathrm{Km}$ ) allotypes in some Pyrenean populations of France. Coll A ntropol 1989; 13: $43-50$.

12 Hazout S, Dugoujon J M, L oirat F, Constans J: G enetic similarity maps and immunoglobulin allotypes of eleven populations from the Pyrenees (France). A nn H um G enet 1991; 55: 161-174.

13 Cavalli-Sforza LL, M enozzi P, Piazza A : History and $\mathrm{G}$ eography of $\mathrm{H}$ uman $\mathrm{G}$ enes. Princeton U niversity Press, Princeton, NJ, 1994.

14 A guirre A I, Vicario A, Mazon LI et al: A K 1, PGD, GC and $H P$ frequencies in the $B$ asque population: a review. Gene $\mathrm{G}$ eography 1989; 3: 41-45.

15 M anzano C, A guirre A I, I riondo M, M artín M, O saba L, de la R úa $C$ : $G$ enetic polymorphisms of the B asques from Gipuzkoa: genetic heterogeneity of the Basque population. Ann Hum Biol 1996; 23: 285-296.

16 Cava A : El neolítico en al País Vasco. Munibe 1990; 42: 97-106.
17 U rbeltz JA : Reflexiones sobre la danza. Euskal dantza tradizionala. In: J. Intxausti (ed.): E uskal H erria: H istoria eta G izartea. Caja Laboral Popular-L an Kide A urrezkia, 1985, pp437-488.

18 De la R úa C: L os estudios de paleoantropología en el País Vasco. M unibe (A ntropología-A rqueología) 1990; 42: 199-219.

19 M anzano C, O rue J M , de la R uac: The 'B asqueness' of the $B$ asques of A lava: A reappraisal from a multidisciplinary perspective. A m J P hys A nthrop 1996; 99: 249-258.

20 A rminio $M L$, Gómez $P$ : Niveles de endogamia y consanguinidad en la población de los Montes de Pas (Cantabria, España).. V Congreso Español de A ntropología Biológica, León, 1987, pp275-284. Ed. U niversidad de L eón, L eón (E spaña).

21 De Grado M, E steban E, M oral P: Polimorfismos genéticos en la población de los $M$ ontes de Pas. In: $N$ ieto J $L$ and Moreno $L$ (eds) Avances en Antropología ecológica y genética, U niversidad de Z aragoza, 1995, pp 315-320.

22 Field LL, D ugoujon J M : I mmunoglobulin allotyping ( $G$ m and $\mathrm{Km}$ ) of GAW 5 families. G enet Epidemiol 1989; 6: 31-34.

23 Edwards AWF: L ikelihood. Cambridge U niversity Press, Cambridge, 1984.

24 W right S: E volution and the genetics of populations. Vol. 4. Variability within and among natural populations U niversity Chicago Press, Chicago, 1978.

25 Workman PL, N isvander J D : Population studies on southwestern Indian Tribes. II. L ocal genetic differentiation in the Papago. A m J H um G enet 1970; 22: 24-49.

26 Felsenstein J: PHYLIP. Phylogeny Inference Package (version 3.2). Cladistics 1989; 5: 164-166.

27 Cavalli-Sforza LL, Edwards WF: Phylogenetic analysis: models and estimation procedures. A m J H um G enet 1967; 19: 233-257.

28 Reynolds J, Weir B S, Cockerham CC: Estimation on the coancestry coefficient: basis of a short-term genetic distance. G enetics 1983; 105: 757-779.

29 Nei M, Roychoudhury AK: Gene differences between Caucasian, N egro and Japanese populations. Science 1972; 177: 434-435.

30 Efron B: The Jacknife, the Bootstrap and Other Resampling Plans. Philadelphia, PA : Society for Industrial and A pplied Mathematics, 1982.

$31 \mathrm{H}$ arperding $\mathrm{HC}$, Jenkins $\mathrm{T}$ : Genetic distance among southern A frican populations. In: Crawford $\mathrm{MH}$ and Workman PL (eds) M ethods and Theories of A nthropological Genetics, U niversity of $\mathrm{New}$ Mexico Press, A lbuquerque, 1973, pp177-199.

32 Blanc $M, D$ ucos J : L es allotypes des systèmes $G M$ et $K M$ dans les provinces françaises. In: O hayon $E$ and CambonThomsen A (eds.) Génétique des populations humaines, Coll INSERM, 1986, vol. 142, pp 207-226.

33 Piazza $A$, van L oghem $E$, de $L$ ange $G$, Curtoni $E S$, U lizzi $L$, Terrenato $L$ : I mmunoglobulin allotypes in Sardinia. A m J H um G enet 1976; 28: 77-86.

34 Lefranc $G$, de $L$ ange $G, R$ ivat $L$ et al: $G m, A m$ and $K m$ immunoglobulin allotypes of two populations of Tunisia. H um G enet 1979; 50: 199-211.

35 Chaabani $\mathrm{H}, \mathrm{H}$ elal $A \mathrm{~N}$, van L oghem $\mathrm{E}$ et al: $\mathrm{G}$ enetic study of Tunisian Berbers. I. G m, A m and $\mathrm{Km}$ immunoglobulin allotypes and ABO groups. J Immunogen 1984; 11: 107-113. 
36 Chaabani H, Cox DW: G enetic characterization of Tunisian Berbers. H um H ered 1988; 38: 308-316.

37 Helal A N, R ivat $L$, van $L$ oghem $E$, de $L$ ange $G, L$ anganey $A$, Lefranc $G$ : Further contribution of common $\mathrm{GM} *-A \mathrm{~m}^{*}$ haplotypes and $\mathrm{Km}$ * alleles on the characterization of the Tunisian population. Expl Clin Immunogenet 1988; 5: 1-14.

38 D ugoujon J M , B orot N, Chaventré A, R udan P: G m and $\mathrm{Km}$ immunoglobulin allotypes in the Olib and Silba islands (N orthern D almatia, Y ugoslavia. Coll A ntrop 1989; 13: 291-297.
39 M oral P, M arogna G, Salis M, Succa V, Vona G : G enetic data on A Ighero population (Sardinia): C ontrast between biological and cultural evidence. A m J Phys A nthrop 1994; 93: 441-453. 